\title{
Limitations of protein-coated charcoal in the separation of free from bound vitamin $B_{12}$ in serum
}

\author{
ELIZABETH JACOB, KIT-TAI J WONG \\ From the Department of Medicine, University of Manitoba, St Boniface Hospital, Winnipeg, Manitoba
}

SUMMARY The effect of haemoglobin and albumin-coated charcoal on the concentration of vita-? min $B_{12}$ binding proteins in serum has been investigated. As commonly employed, coated char- $\%$ coal removes a significant amount of transcobalamin II (TCII) from serum, but does not affect transcobalamin I and III (TCI and III). Increasing the protein coat up to about $10 \mathrm{mg}$ of protein N per $25 \mathrm{mg}$ of charcoal reduces the adsorption of TCII, but increasing the protein concentration $\circ$

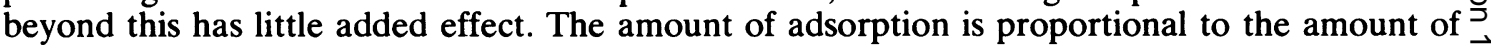
coated charcoal employed, but even small amounts adsorb some TCII. These results indicate that $\vec{\rho}$ protein-coated charcoal is not the ideal way of separating free from bound vitamin $B_{12}$ in serum; $\frac{\mathbb{D}}{D}$ it cannot reliably be used for the measurement of the concentration of apo-TCII but can be employed for the measurement of apo-TCI and III.

There are two major vitamin $B_{12}$ binding proteins in human serum, transcobalamins I and III and transcobalamin II. Transcobalamins I and III (TCI and III), also known as cobalophilin, are mainly saturated with vitamin $B_{12}$ and probably serve a storage function. Transcobalamin II (TCII) is mainly unsaturated and is the major transport protein for the vitamin. The unsaturated (apo) TCI and III and TCII together constitute the unsaturated vitamin $B_{12}$ binding capacity of serum. To measure this, it is the practice to add excess radioactive labelled vitamin $B_{12}$ which saturates all the binding sites and leaves excess free radioactive vitamin $B_{12}$. The next step involves separating the bound from the free vitamin $B_{12}$ for which a number of methods have been described including microbiological assay, ${ }^{1}$ electrophoresis, ${ }^{1}$ dialysis, ${ }^{2}$ gel filtration, ${ }^{3}$ ultrafiltration, ${ }^{4}$ and adsorption with haemoglobin-coated ${ }^{5}$ or albumin-coated ${ }^{6}$ charcoal. Because of its simplicity, the coated charcoal method has achieved wide popularity.

In measuring the concentration of apo-TCII in serum, it was noted that treatment with coated charcoal appeared to decrease the amount of measurable TCII. We report the results of a systematic study of this phenomenon.

\section{Material and methods}

Sera were obtained from normal volunteers atdo from patients undergoing therapeutic phlebotomy. The blood was allowed to clot at room temperature the serum separated and frozen in aliquots at $-20^{\circ} \mathrm{C} \frac{\mathrm{O}}{\mathrm{Q}}$ until used.

RADIOACTIVE VITAMIN B

Vitamin $\mathrm{B}_{12}$ labelled with ${ }^{57} \mathrm{Co}\left({ }^{57} \mathrm{CoB}_{12}\right)$ with specific activity of approximately $15.0 \mu \mathrm{Ci} / \mu \mathrm{g}$ was. obtained from Amersham Corporation.

\section{ZIRCONYL PHOSPHATE GEL}

Zirconyl chloride $\left(\mathrm{ZrOCl}_{2} .8 \mathrm{H}_{2} \mathrm{O}\right)$ was obtained from BDH Chemicals Ltd. Zirconyl phosphate geß $\mathrm{pH} 6.25$ (Z-gel) was prepared according to the method of Hansen et al. ${ }^{7}$ This was used to measure the apo-TCII concentration of serum by the methodo of Tan and Hansen ${ }^{8}$ as modified by Sonneborn et al ${ }^{9}$. with minor changes. Five hundred picogramso ${ }^{57} \mathrm{CoB}_{12}$ in $1.0 \mathrm{ml}$ saline was added to duplicate aliquots of $0.1 \mathrm{ml}$ serum and the mixtures incubated an room temperature for $30 \mathrm{~min} ; 2.5 \mathrm{ml}$ of $\mathrm{Z}$-gel and $5.0 \mathrm{ml}$ of $0.1 \mathrm{~mol} / \mathrm{l}$ ammonium acetate $\mathrm{pH} 6.25$, were added. The tubes were mixed, centrifuged at $1600 \mathrm{~g}$ for $5 \mathrm{~min}$, the supernatant decanted, the sed iment washed with another $5 \mathrm{ml}$ ammonium acetate solution and the radioactivity of the pellet measure $\$$ in a well scintillation counter. 
COATED CHARCOAL

The following charcoal preparations were investigated:

1 Norit "A", pharmaceutical grade, neutral charcoal, from Amend Drug and Chemical Company, lot no B10311H18.

2 The same as above but lot no D11718B01.

3 DARCO G-60 activated carbon from Fisher Scientific Company, lot no 746274.

4 Norit A, neutral, pharmaceutical charcoal powder for decolorising from BDH Chemicals, lot no $83116 / 3417$.

5 Norit SG activated charcoal powder from MCB Manufacturing Chemists.

Haemoglobin-coated charcoal was prepared according to the method of Lau et $a^{5}$ using one part of haemoglobin (prepared from human red cells) to 10 parts of charcoal. Albumin-coated charcoal was prepared as described by Gottlieb et $a l^{6}$, using one part of albumin to five of charcoal.

\section{VITAMIN $B_{12}$-SATURATED CHARCOAL TREATED SERUM}

This was prepared by the method of Scott et al..$^{10}$ Five hundred picograms of ${ }^{57} \mathrm{CoB}_{12}$ in $1 \mathrm{ml}$ of saline was added to $0.1 \mathrm{ml}$ of serum. This amount of ${ }^{57} \mathrm{CoB}_{12}$ was in excess of the vitamin $\mathrm{B}_{12}$ binding capacity of the serum. The mixture was incubated at room temperature for $30 \mathrm{~min}$. An aliquot $(1.0 \mathrm{ml})$ of coated charcoal, containing $25 \mathrm{mg}$ charcoal, was then added to adsorb the free ${ }^{57} \mathrm{CoB}_{12}$, the tube mixed on a vortex mixer, centrifuged, and the supernatant serum decanted; this is hereafter termed charcoal-treated serum.

\section{SEPHADEX GEL FILTRATION}

Sephadex gel filtration experiments were carried out using Sephadex G-150 in a $2.5 \times 100 \mathrm{~cm}$ column. Serum $(500 \mu \mathrm{l})$ was applied to the column and eluted with $0.04 \mathrm{~mol} / \mathrm{l}$ phosphate buffer containing $0.5 \mathrm{~mol} / \mathrm{l} \mathrm{NaCl}, \mathrm{pH} 7 \cdot 38$. Fractions $(4 \mathrm{ml})$ were collected, the optical density measured at $280 \mathrm{~nm}$ and the radioactivity of the fractions determined using a well scintillation counter. The radioactivity of the fractions included in the TCI and III and the TCII peaks were summed to give the respective amounts of these vitamin $B_{12}$ binding apoproteins. It was found that the charcoal-treated serum, in spite of extensive centrifugation, contained a small amount of charcoal particles which tended to block the column. Experiments showed that aliquots of sera directly applied to the column, or passed through an $0.45 \mu \mathrm{m}$ millipore filter, contained identical amounts of vitamin $B_{12}$ binders. The charcoaltreated serum was therefore passed through such a filter and $500 \mu$ lof the filtrate applied to the column.

\section{PURIFICATION OF TCII}

TCII was purified from Cohn Fraction III* prepared from human plasma as described by Savage et al. ${ }^{11}$ This purified material was shown to be free of cobalophilin by sodium dodecyl sulphatepolyacrylamide gel electrophoresis*.12 The purified TCII was saturated with ${ }^{57} \mathrm{CoB}_{12}$ and $340 \mu \mathrm{g}$ of this protein combined with $1.0 \mathrm{ml}$ of Freund's adjuvant was injected into the foot pads of each of three New Zealand white rabbits. Twenty-three days later a repeat injection containing $85 \mu \mathrm{g}$ of the same material with $0.5 \mathrm{ml}$ Freund's adjuvant was given. The rise in TCII antibody titre as measured by PEG precipitation, ${ }^{13}$ was followed weekly and serum collected when the antibody titre was $1200 \mathrm{ng} / \mathrm{ml}$ or more. This antibody was used to confirm the identity of the TCII peak in Sephadex column chromatography experiments. The addition of the antibody caused the peak to be shifted to the void volume.

*See acknowledgements.

\section{Results}

Effect of coated charcoal on apo-TCII concentration ${ }^{57} \mathrm{CoB}_{12}$ was added to seven sera in more than ade-

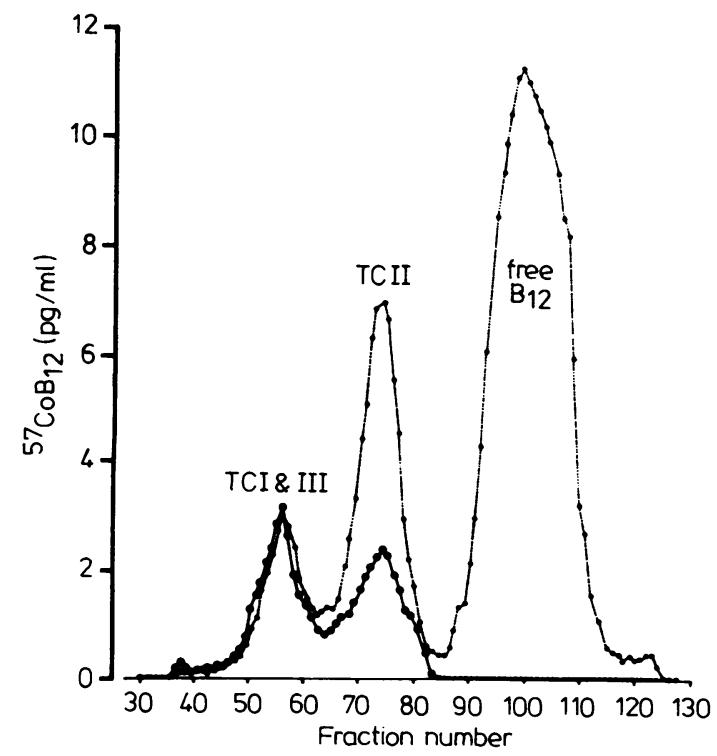

Fig. 1 Representative Sephadex G-150 column chromatography experiment. ${ }^{57} \mathrm{CoB}{ }_{12}$ was added to a serum in excess of its binding capacity. One aliquot was applied directly to the column (O.........) and one was pretreated with haemoglobin-coated charcoal (O- It will be seen that treatment with charcoal removed the free ${ }^{57} \mathrm{CoB}{ }_{12}$ and a significant amount of TCII. 
Table 1 Apo-TCII concentration $(\mathrm{pg} / \mathrm{ml})$

\begin{tabular}{ccccc}
\hline & $\begin{array}{c}\text { Before haemoglobin-coated } \\
\text { charcoal }\end{array}$ & \multicolumn{2}{c}{$\begin{array}{c}\text { After haemoglobin-coated } \\
\text { charcoal }\end{array}$} \\
\cline { 2 - 5 } & Sephadex & $Z$ gel & Sephadex & Z gel \\
\hline 1 & 998 & 986 & 646 & 577 \\
2 & 862 & 819 & 569 & 509 \\
3 & 554 & 558 & 212 & 264 \\
4 & 1560 & 1528 & 911 & 946 \\
5 & 870 & 868 & 625 & 600 \\
6 & 714 & 704 & 373 & 449 \\
7 & 1038 & 946 & 611 & 685 \\
\hline
\end{tabular}

quate amounts to saturate all the vitamin $B_{12}$ binders. Each serum was then divided into two aliquots, one of which was treated with haemoglobin-coated charcoal using charcoal No $1(25 \mathrm{mg}$ in $1 \mathrm{ml})$ as described above. The TCII content of each aliquot was then determined both by the Z-gel assay and by Sephadex G-150 column chromatography. A representative column chromatography experiment is shown in Fig. 1 and the results for the seven sera are shown in Table 1. It will be seen that there is good agreement between the two methods for measurement of apo-TCII, but in each case there is a substantial reduction in the apparent TCII concentration in the charcoal treated sera which ranged from 28 to $62 \%$.

On five different occasions, three aliquots of one serum were taken. Excess ${ }^{57} \mathrm{CoB}_{12}$ was added to each aliquot. On the first aliquot the apo-TCII content was estimated by the $\mathrm{Z}$-gel assay. The mean \pm SD TCII content was $1080 \pm 54 \mathrm{pg} / \mathrm{ml}$. The free ${ }^{57} \mathrm{CoB}_{12}$ in the second and third aliquots was removed with albumin-coated charcoal or haemoglobin-coated charcoal. The apo-TCII concentration of the second aliquot was then estimated by the Z-gel assay. The mean \pm SD was $674 \pm 63$ $\mathrm{pg} / \mathrm{ml}$. To the third aliquot further ${ }^{57} \mathrm{CoB}_{12}$ was added and a Z-gel assay for apo-TCII performed. The mean $\pm S D$ was $733 \pm 35 \mathrm{pg} / \mathrm{ml}$. The failure of

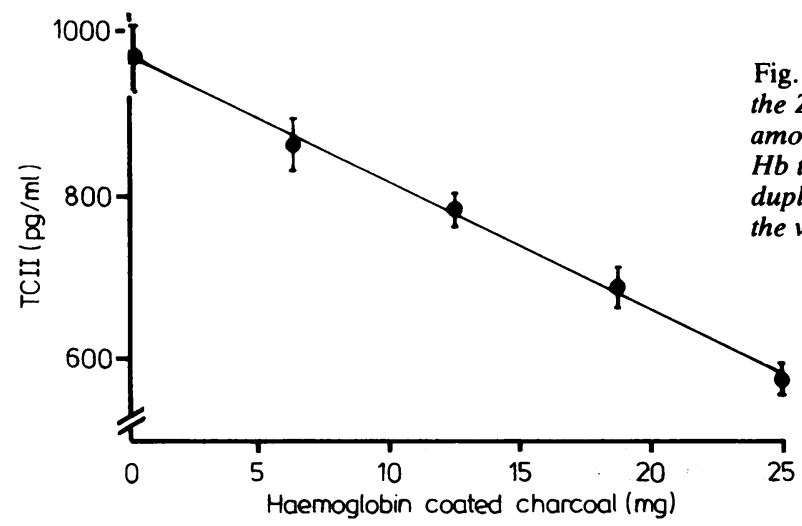

the addition of further ${ }^{57} \mathrm{CoB}_{12}$ to restore the ${ }^{70}$ measurable apo-TCII to the value in the first aliquot $\vec{F}$

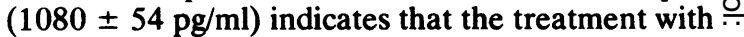
protein-coated charcoal has removed TCII and not simply removed ${ }^{57} \mathrm{CoB}_{12}$ from its binding with TCII.

Effect of coated charcoal on apo-TCI and III

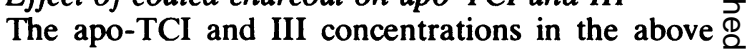
seven sera before and after treatment with haemoglobin-coated charcoal were measured by Sephadex G-150 column chromatography (Fig. 1). ? The results for the seven sera are shown in Table 2 .

\section{Effect of amount of coated charcoal}

${ }^{57} \mathrm{CoB}_{12}$ was added to a serum in more than adequ- $\dot{\omega}$ ate amounts to saturate all the vitamin $B_{12}$ binders.

Table 2 Apo-TCI and III concentrations $(\mathrm{pg} / \mathrm{ml})$ as measured by Sephadex gel filtration

\begin{tabular}{lccc}
\hline $\begin{array}{c}\text { Before haemoglobin-coated } \\
\text { charcoal }\end{array}$ & $\begin{array}{c}\text { After haemoglobin-coated } \\
\text { charcoal }\end{array}$ \\
\hline 1 & 593 & 577 & \\
2 & 132 & 150 & \\
3 & 197 & 217 & \\
4 & 563 & 529 & \\
5 & 184 & 149 & O \\
6 & 283 & 278 & 238 \\
7 & 223 & & \\
\hline
\end{tabular}

This was divided into five aliquots and amounts of haemoglobin-coated charcoal (charcoal No $\overrightarrow{\mathrm{I}}$ ) ranging from 6.25 to $25 \mathrm{mg}$ added to four of them. The TCII content of the untreated and the $\frac{Q}{\mathbb{Q}}$ charcoal-treated aliquots were then measured by the $\mathrm{Z}$-gel assay in duplicate. This was done on five different occasions on the same serum and the mean and standard deviation of the TCII concentrations for each of the aliquots estimated. The results are shown in Fig. 2. It will be seen that there is a linear reduction in measurable apo-TCII concentration

Fig. 2 The apo-TCII content of a serum as measured by the Z-gel assay directly and after adsorption with different amounts of haemoglobin-coated charcoal using one part of $\mathrm{Hb}$ to ten of charcoal. Each point represents the mean of duplicate observations made on five different occasions and he vertical lines, the standard deviations of the means. 
Table 3 Apo-TCII concentration (pg/ml) as measured by $Z$ gel assay

\begin{tabular}{|c|c|c|c|c|c|c|}
\hline \multirow[b]{2}{*}{ Serum } & \multirow[b]{2}{*}{$\begin{array}{l}\text { Without } \\
\text { charcoal }\end{array}$} & \multicolumn{5}{|c|}{ Haemoglobin-coated charcoal } \\
\hline & & $\underset{1}{\text { Charcoal }}$ & $\begin{array}{c}\text { Charcoal } \\
2\end{array}$ & $\begin{array}{c}\text { Charcoal } \\
3\end{array}$ & $\underset{4}{\text { Charcoal }}$ & $\begin{array}{c}\text { Charcoal } \\
5\end{array}$ \\
\hline \multirow[t]{2}{*}{$\begin{array}{l}1 \\
2 \\
3\end{array}$} & $\begin{array}{l}687 \\
854 \\
539\end{array}$ & $\begin{array}{l}503 \\
591 \\
331\end{array}$ & $\begin{array}{l}502 \\
608 \\
356\end{array}$ & $\begin{array}{l}367 \\
432 \\
235\end{array}$ & $\begin{array}{l}498 \\
633 \\
380\end{array}$ & $\begin{array}{l}573 \\
722 \\
430\end{array}$ \\
\hline & & \multicolumn{5}{|c|}{ Albumin-coated charcoal } \\
\hline $\begin{array}{l}4 \\
5 \\
6\end{array}$ & $\begin{array}{l}869 \\
710 \\
605\end{array}$ & $\begin{array}{l}509 \\
445 \\
264\end{array}$ & $\begin{array}{l}529 \\
458 \\
214\end{array}$ & $\begin{array}{l}577 \\
510 \\
332\end{array}$ & $\begin{array}{l}609 \\
557 \\
338\end{array}$ & $\begin{array}{l}678 \\
560 \\
402\end{array}$ \\
\hline
\end{tabular}

with the addition of increasing amounts of haemoglobin-coated charcoal.

Effect of the amount of protein used to coat the charcoal

Haemoglobin-coated charcoal using charcoal No 1 was prepared with amounts of haemoglobin $(\mathrm{Hb})$ ranging from 1.25 to $25 \mathrm{mg}$ of $\mathrm{Hb}$ per $25 \mathrm{mg}$ of charcoal. Similarly albumin-coated charcoal using charcoal No 1 was prepared with amounts of albumin ranging from 2.5 to $25 \mathrm{mg}$ per $25 \mathrm{mg}$ of charcoal. The effect of $25 \mathrm{mg}$ of these different coated charcoals on the apo-TCII content of $0 \cdot 1 \mathrm{ml}$ aliquots of a serum was measured in duplicate by the Z-gel assay. The results are shown in Fig. 3. As the ratio of protein to charcoal is increased, the amounts of apo-TCII remaining in the serum increases, but from $10 \mathrm{mg}$ of protein to $25 \mathrm{mg}$ of protein per $25 \mathrm{mg}$ of charcoal there is little change.

\section{Effect of different charcoal preparations}

Three sera were divided into aliquots and the apoTCII content measured by the Z-gel assay, both directly and after treatment with haemoglobin- coated charcoal ( $25 \mathrm{mg}$ charcoal) prepared from the five different lots of charcoal listed under material and methods, using one part of haemoglobin to ten of charcoal. Three sera were similarly investigated using albumin-coated charcoal (25 mg charcoal) prepared from the five different lots of charcoal using one part of albumin to five of charcoal. The results are shown in Table 3 . In each case, the various coated charcoals reduce the amount of measurable apo-TCII.

\section{Discussion}

Miller ${ }^{14}$ appears to have been the first to describe the use of charcoal adsorption to separate free from protein-bound vitamin $B_{12}$ in serum. However, Gregory and Holdsworth ${ }^{15}$ and Ardeman and Chanarin $^{16}$ showed that activated charcoal would also adsorb some vitamin $B_{12}$ binding proteins. Gottlieb et $a l^{6}$ suggested that the charcoal should first be coated with another protein to prevent this. They added excess radioactive vitamin $B_{12}$ to $0.5 \mathrm{ml}$ of serum and added $50 \mathrm{mg}$ of albumin-coated charcoal (one part of albumin to five of charcoal by weight) to

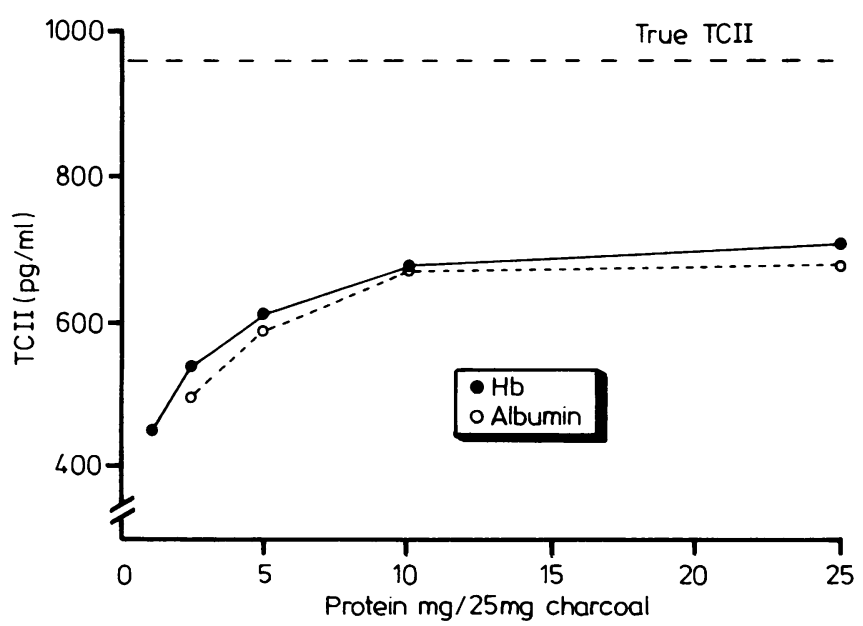

Fig. 3 The measurable apo-TCII concentrations of $0.1 \mathrm{ml}$ aliquots of a serum treated with $25 \mathrm{mg}$ of charcoal coated with different amounts of $\mathrm{Hb}$ and albumin. The left most point on the former represents $a$ concentration of one part of $\mathrm{Hb}$ to 20 of charcoal as advocated by Lau et al. ${ }^{5}$ The second point from the left on the latter corresponds with the concentration of one part of albumin to five of charcoal as recommended by Gottlieb et al. ${ }^{\circ}$ The horizontal dotted line is the "true" apo-TCII concentration as measured by the Z-gel assay without exposure to coated charcoal. 
remove the free radioactive vitamin $B_{12}$ and assumed that the radioactivity remaining in the supernatant was a measure of the unsaturated vitamin $B_{12}$ binding capacity of the serum. The same workers $^{5}$ later also recommended haemoglobin as a coating agent (one part of haemoglobin solution to 20 of charcoal by weight). Subsequently Scott $e a^{10}$ from the same laboratory, used this haemoglobincoated charcoal in the ratio of $25 \mathrm{mg}$ of charcoal to $0.1 \mathrm{ml}$ of serum to remove excess free radioactive vitamin $B_{12}$.

Adams and McEwan ${ }^{17}$ made a systematic study of several methods for separating bound from free vitamin $B_{12}$. They noted that the results using charcoal could be significantly affected by a number of factors including the type of binder, the form of vitamin $B_{12}$, the type and amount of charcoal and the amount of coating. However, they did not study the vitamin $B_{12}$ binding proteins of serum. Stenman ${ }^{18}$ also found that coated charcoal adsorbed some vitamin $B_{12}$ binding proteins, especially from samples with a low protein content. Begley and Hall ${ }^{19}$ reported that the use of albumin-coated charcoal as recommended by Gottlieb et $a l^{6}$ reduced the apparent unsaturated vitamin $B_{12}$ binding capacity of serum by about $10 \%$, but did not determine which binding proteins were adsorbed.

Our accidental finding that the apparent apo-TCII concentration of a serum as measured by the Z-gel assay was considerably reduced by prior treatment with haemoglobin-coated charcoal prompted this study. The results of the Z-gel assay on other sera before and after treatment with coated charcoal (Table 1) indicated that this reduction was a constant phenomenon. We have further shown that this reduction is due to adsorption of TCII and not to the splitting off of ${ }^{57} \mathrm{CoB}_{12}$ from its binding with TCII. Sephadex G-150 column chromatography confirmed that the reduction of vitamin $B_{12}$ binding protein was confined to apo-TCII and that there was no reduction in the concentration of apo-TCI and III (Fig. 1 and Table 2). The experiments illustrated in Fig. 2 show that the amount of apo-TCII adsorbed increases stoichiometrically with the amount of coated charcoal added. If $50 \mathrm{mg}$ of coated charcoal is used with $0.5 \mathrm{ml}$ of serum as recommended by Gottlieb et $a l^{6}$ (or $10 \mathrm{mg} / 0 \cdot 1 \mathrm{ml}$ serum), then the adsorption of TCII will be proportionately reduced. However, even in these proportions, there will still be a loss of up to $25 \%$ of apoTCII in some sera. Furthermore, if the amount of coated charcoal used is reduced too much, all the free vitamin $B_{12}$ added to the serum may not be adsorbed. ${ }^{17}$

To see whether increasing the amount of protein coating the charcoal would prevent the adsorption of apo-TCII, experiments were carried out with increasing amounts of haemoglobin and albumin coating (Fig. 3). The amount of apo-TCII adsorbed decreased with increasing protein concentration up to about $10 \mathrm{mg}$ of protein per $25 \mathrm{mg}$ of charcoal, but increasing the concentration beyond this point had little effect. Even when equal amounts of protein and charcoal were employed, there was still significant reduction in the amount of measurable apo-TCII.

Herbert $e a^{20}{ }^{20}$ stressed the importance of the type of activated charcoal used and stressed that it must be "Norit 'A' pharmaceutical grade neutral charcoal, purchased from Amend Drug and Chemical Company, New York". Two different batches of this particular charcoal gave similar results, as did three other commercially available brands of charcoal. The adsorption of TCII by protein-coated charcoal therefore seems to be a generalised property, independent of the type of charcoal.

It is apparent from these studies that the use of haemoglobin or albumin-coated charcoal is not a reliable technique for quantitatively separating bound from free vitamin $\mathrm{B}_{12}$ in serum. When employed in the measurement of unsaturated vitamin $\mathrm{B}_{12}$ binding capacity or apo-TCII concentration in serum, falsely low values will result. However, since it does not adsorb TCI and III its use is valid for the measurement of these serum binders. Finally, thi study suggests that when serum is used as the bindef in radioisotope dilution assays for vitamin $B_{12}$, the use of protein-coated charcoal to separate bound from free vitamin $B_{12}$ needs to be reassessed.

This work was supported by grants from St Boniface General Hospital Research Foundation and the Medical Research Council of Canada.

The Cohn fraction III preparation was kindly donated by Mr Johan Vandersande of the New York Blood Centre, New York, USA.

The sodium dodecyl sulphate-polyacrylamide gel electrophoresis was kindly performed by Dr Fritz Stevens, Department of Biochemistry, University of Manitoba, Winnipeg, Canada.

\section{References}

' Pitney WR, Beard MF, Van Loon EJ. Observations on the bound form of vitamin $B_{12}$ in human serum. $J$ Biol Chem 1954;207:143-52.

${ }^{2}$ Rosenthal HL, Sarett HP. Determination of vitamin $B_{12}$ activity in human serum. J Biol Chem 1952;199:433-42.

${ }^{3}$ Daisley KW. Gel filtration of sea-water: separation of free and bound forms of vitamin $B_{12}$. Nature $1961 ; 191: 868-9$.

- Gregory ME, Holdsworth ES. The occurrence of a cyanocobalamin binding protein in milk and the isolation of a cyanocobalamin protein complex from sow's milk. Biochem $\mathrm{J}$ 1955;59:329-34. 
s Lau K-S, Gottlieb C, Wasserman LR, Herbert V. Measurement of serum vitamin $B_{12}$ level using radioisotope dilution and coated charcoal. Blood 1965;26:202-14.

- Gottlieb C, Lau K-S, Wasserman LR, Herbert V. Rapid charcoal assay for intrinsic factor (IF), gastric juice unsaturated $B_{12}$ binding capacity, antibody to IF, and serum unsaturated $B_{12}$ binding capacity. Blood 1965;25:875-84.

${ }^{7}$ Hansen HJ, Miller ON, Gallo-Torres H, Goldsmith GA. Assay of intrinsic factor activity of human gastric juice with zirconyl phosphate gel. Anal Biochem 1966;16:287-93.

${ }^{8}$ Tan CH, Hansen HJ. Studies on the site of synthesis of transcobalamin II. Proc Soc Exp Biol Med 1968;127:740-4.

9 Sonneborn DW, Baskerville AB, Regelson W. Levels of transcobalamin II in normal human serum measured with zirconyl phosphate gel. Scand J Haematol 1973;11:8-12.

${ }^{10}$ Scott JM, Bloomfield FJ, Stebbins R, Herbert V. Studies on derivation of transcobalamin III from granulocytes: enhancement by lithium and elimination by fluoride of in vitro increments in vitamin B -binding capacity. J Clin Invest 1974;53:228-39.

"Savage CR, Meehan AM, Hall CA. Improved method for the purification of biologically active transcobalamin II. Prep Biochem 1976;6:99-111.

12 Studier FW. Analysis of bacteriophage T7 early RNA's and proteins on slab gels. J Mol Biol 1973;79:237-48.
${ }^{13}$ Morelli T, Savage CR, Begley JA, Hall CA. Radioimmunoassay for serum transcobalamin II.J Lab Clin Med 1977;89:645-52.

14 Miller ON. Determination of bound vitamin $B_{12}$. Arch Biochem Biophys 1957;68:255-62.

${ }^{15}$ Gregory ME, Holdsworth ES. A study of protein-binding in the metabolism of vitamin $B_{12}$. Biochem $J$ 1959;72:549-56.

${ }^{16}$ Ardeman S, Chanarin I. Gastric intrinsic factor (letter). Lancet $1964 ; \mathrm{i}: 384$ and 1040.

17 Adams JF, McEwen FC. The separation of free and bound vita$\min B_{12}$. Br J Haematol 1974;26:581-92.

18 Stenman U-H. Intrinsic factor and the vitamin $B_{12}$ binding proteins. Clin Haematol 1976;5:473-95.

19 Begley JA, Hall CA. Measurement of vitamin $B_{12}$-binding proteins of plasma. I. Technique. Blood 1975;45:281-6.

${ }^{20}$ Herbert V, Gottlieb CW, Lau K-S. Hemoglobin-coated charcoal assay for serum vitamin $B_{12}$ (letter). Blood 1966;28:130-2.

Requests for reprints to: Dr E Jacob, Department of Medicine, St Boniface Hospital, 409 Tache Avenue, Winnipeg, Manitoba R2H 2A6, Canada. 